\title{
ROS1 Fusion Negative
}

National Cancer Institute

\section{Source}

National Cancer Institute. ROS1 Fusion Negative. NCI Thesaurus. Code C142839.

An indication that the expression of a fusion involving ROS1 has not been detected in a sample. 